\title{
Socio-sexual signalling and gonadal function: Opportunities for reproductive management in domestic ruminants
}

\author{
R Ungerfeld \\ Departamento de Fisiologia, Facultad de Veterinaria, Lasplaces 1550, Montevideo 11600, Uruguay
}

\begin{abstract}
The aims of this review are to summarize the common biological basis of the responses to social stimulus in domestic ruminants and to consider the research still required in order to put this knowledge to practical use on the farm. The mechanisms involved in the stimulation of sheep and goat females, including both the expected ovarian and behavioural responses, are described. In most breeds, the male effect may be used effectively to induce ovulation during seasonal anoestrus. Although good responses have been obtained in most sheep trials, in some experiments using more seasonal breeds of sheep, poor responses were observed. In goats, it seems that this can be partially overcome if teaser bucks are adequately stimulated (by light treatment and melatonin administration). The strategic use of these stimuli to induce fertile ovulations during the postpartum period is also discussed. In cattle, less is known about the physiological mechanisms by which cows respond to stimulation from the bull. Most trials have focused in trying to advance postpartum rebreeding, with very diverse outcomes. The wide variety of interacting factors and the paucity of data make it difficult to draw conclusions regarding the use of social stimuli in postpartum management. The challenge for researchers is to develop social management techniques that will induce oestrus and ovulation whenever farmers require them. Although more research is necessary to improve efficacy in some sheep breeds and in postpartum animals, social stimulation emerges as an inexpensive and hormone-free strategy that may be useful for farmers.
\end{abstract}

\section{Introduction}

Reproduction is a consequence of endogenous neuroendocrine regulating mechanisms and external factors that interact with them. Environmental conditions interact with the endogenous system by either stimulating or inhibiting physiological mechanisms and many of these mechanisms are related to the reproductive axis. In ruminants, social cues may act to either stimulate or inhibit reproductive activity. Social hierarchies or suckling are examples of inhibitory cues, which may be considered in management practice. On the other hand, there is considerable evidence that males may stimulate oestrus and ovulation in anovulatory females: the so called "male effect". Research on the use of the male effect has been increasing recently (Ungerfeld 
2005), probably as a consequence of being described as a "clean, green, and ethical" practice (Martin et al. 2004).

The effects of social stimuli on reproductive physiology have been widely demonstrated in rodents and several farm species. In ruminants, several reproductive responses may be obtained in females following male stimulation (as in the male effect: Table 1). Although there is only preliminary information, male stimuli on female reproductive physiology may also exist in caribou, musk deer and camels (Green 1987; Claus et al. 1999; Adams et al. 2001).

Table 1. Ruminant species in which the male effect has been demonstrated and the main effects on the females.

\begin{tabular}{lll}
\hline Species & Effect & Reference \\
\hline Sheep & Induction of oestrus in seasonal anoestrus & Underwood et al. 1944 \\
& Shortening of postpartum in ewes & Geytenbeek et al. 1984 \\
Goat & Advancement of puberty in lambs & O'Riordan \& Hanrahan 1989 \\
& Advancement of puberty in goats & Chemineau 1985 \\
& Synchronization of puberty onset & Mellado et al. 2000 \\
Cattle & Advancement of postpartum rebreeding & Amoah \& Bryant 1984 \\
& Advancement of puberty & Zalesky et al. 1984 \\
Red deer & Advancement of the breeding season & Rekwot et al. 2000 \\
& Advancement of puberty & Moore \& Cowie 1986 \\
Eld's deer & Advancement of oestrus and the LH peak & Fisher et al. 1995 \\
Fallow deer & Advancement of the breeding season & Hosack et al. 1999 \\
Reindeer & Advancement of onset of breeding season & Komers et al. 1999 \\
Moose & Synchronization of the breeding season & Shipka et al. 2002 \\
& Induction of ovulation & Whittle et al. 2000 \\
Antelope & Modification of oestrous cycle duration & Miquelle 1991 \\
Oryx & Advancement of puberty & Skinner et al. 2002 \\
Impala & Advancement of the breeding season & Blanvillain et al. 1997 \\
Blesbok & Increase in length of breeding season & Skinner et al. 1992 \\
\hline
\end{tabular}

The female reproductive responses to the male effect have been reviewed before (WalkdenBrown et al. 1999; Delgadillo etal. 2004; Ungerfeld etal. 2004a; Delgadillo et al. 2006). In the present review, information regarding the female reproductive responses to male stimulation of sheep and goats during seasonal anoestrus, and sheep, goats and cattle during the postpartum period are compared and summarized and areas in which further research is needed are proposed. In addition new previously unpublished information on sheep and cattle is included.

\section{Male effect: evolutionary advantages}

What is the evolutionary origin of the male effect? Seasonal patterns of reproduction should be a consequence of selective processes related to best environmental conditions for parturition and nursing. To measure the appropriate time for conception, animals would then be forced to use different environmental cues such as photoperiod, temperature, rainfall and nutrition. However, social cues may also trigger the onset of the breeding season in wild and feral ruminants. Domestic animals display some differences in their reproductive physiology compared with their wild ancestors. Wild or feral cattle and swine have short breeding seasons compared to their domesticated counterparts, which have been selected to breed throughout the year (Mauget 1981; Rowlands \& Weir 1984; Reinhardt etal. 1986). The reproductive pattern of sheep is a bit different: wild sheep have a short breeding season and even the most developed breeds retain a seasonal reproductive pattern. 
The high degree of breeding synchrony observed in wild and feral female ruminants may be at least partially a consequence of male introduction and other social interactions. The social structure throughout the year is similar in wild and feral sheep breeds (such as, Soay, Rocky Mountain Bighorn [Ovis canadensis canadensis], Punjab Urial [Ovis orientalis ssp. punjabiensis] and Mouflon), goats and in farmed breeds (Geist 1965; 1971; Grubb \& Jewell 1973; Schaller \& Mirza 1974; Knight et al. 1998; McClelland 1991). Outside the rutting period, social groups are comprised of several females with their offspring while males live in small same-sex groups (Stricklin \& Mench 1987). When male offspring become mature they disperse from the female group (Shackleton \& Schank 1984). Wethers (castrated male sheep) remain together or with females (Jewell 1997), suggesting that the testis (probably through androgens) is involved in segregation. As the time of breeding approaches, males join female groups. Nudging, blocking, rubbing and aggressive behaviours (Jewell 1976; Lincoln \& Davidson 1977) by males begins before females come into oestrus, probably as a consequence of the earlier activation of the male reproductive system (including, increased pulsatile LH secretion and increased circulating concentrations of both FSH and testosterone: Lincoln \& Short 1980). In sheep, natural joining may trigger, through the ram effect, an earlier onset of the breeding season.

The rut period causes an increase in the energy expenditure of males (Jewell 1997). So what is the significance of beginning the reproductive season before females are cyclic? Moreover, what is the sense of having a mechanism where males trigger the female reproductive system? The mechanism may be especially important in breeds that display a very short breeding season (for example, Soay have 1 to 3 oestrous cycles: Grubb \& Jewell 1973). Moreover, late conception in Rocky Mountain Bighorn sheep during the breeding season increases lamb and ewe mortality (Hogg et al. 1992). The male stimuli may also promote an advancement of puberty in females, which may increase their reproductive success throughout their lifetime (Bérubé et al. 1999). The period from joining of males and females until the peak of oestrus may also be useful for males to sort out hierarchical ranks. Oestrous synchronization allows different males to mate different females thereby decreasing the risks of inbreeding and the reduction of genotype variation that would result. Komers et al. (1999) working with fallow deer postulated that the onset of females' cyclic activity in response to males is related to the "quality" of males. If so, females may be able to detect the better quality stimulus emitted by individual males and, if advantages may be obtained, advance their cyclic activity. Overall, the available information suggests that there is an evolutionary mechanism underlying the reproductive response of domestic ewes to the introduction of rams. Understanding this mechanism may allow us to manipulate the breeding activity of farmed breeds.

Considering all this information logether, we speculate that most ruminant females would respond to the introduction of males at least 45 to 60 days before the onset of the breeding season. However, the challenge for researchers is to develop social managements to induce ovulation and oestrus whenever it is desired, and not only close to the breeding season onset, as happens in wild ruminants.

\section{Sheep and goats: the basis of anoestrus and endocrine changes induced by males}

Seasonal anoestrus is associated with reduced $\mathrm{LH}$ pulsatility compared to the breeding season and with an absence of preovulatory surges of $\mathrm{FSH}$ and $\mathrm{LH}$. Low $\mathrm{LH}$ pulsatility is due to two inhibitory mechanisms: (1) an increased negative feedback effect of oestradiol in the hypothalamus; and (2) a direct effect of photoperiod on the hypothalamo-hypophyseal system controlling $\mathrm{LH}$ secretion. 
The introduction of males induces an increase in the pulsatile secretion of $\mathrm{LH}$ in ewes and does (reviewed by Walkden-Brown et al. 1999), which may end with a LH surge followed by ovulation. In ewes, it has been demonstrated that after the introduction of the rams the negative oestradiol-LH feedback switches to a positive, stimulatory feedback but there is also a stimulus independent from oestradiol, acting directly at the hypothalamus-pituitary level (Martin et al. 1983). This response ends with a LH surge, similar to that observed during a follicular phase in cyclic ewes. A silent ovulation occurs, without signs of oestrus. When the corpus luteum (or corpora lutea) regresses after the first ovulation, another ovulation accompanied by oestrus occurs 17 to 19 days after the introduction of the rams. However, in some ewes, the corpus luteum regresses after 4 to 5 days and another silent ovulation takes place. After this ovulation, a corpus luteum of normal life span is formed, followed by oestrus 21 to 25 days after joining ewes and rams. Recently, we observed ultrasonographically other ovarian responses, like delayed ovulations occurring 5 to 7 days after the introduction of rams followed by normal or short luteal phases, or luteinized follicles (Ungerfeld et al. 2002; 2004b).

In goats, the ovarian and behavioural responses differ. An initial ovulation associated with oestrus is observed 2 to 3 days after the introduction of bucks, which is followed in most goats by a short ovarian cycle of 5 to 7 days. Afterwards a second ovulation which is also associated with oestrus occurs and is followed by a normal luteal phase (Delgadillo et al. 2004; 2006). Fig. $1 \mathrm{~A}$ and $1 \mathrm{~B}$ illustrates the more common patterns of response in sheep and goats, respectively. In Fig. 1C, a synthesis of the expected periods in which oestrus may be expected to occur in sheep flocks and goat herds is shown.

If ewes or does are primed with progestogens and then stimulated by teasers, all the first corpora lutea will have normal function. Although some attempts have been made to determine the physiological mechanisms producing each response pattern (normal versus short luteal phase) little has been elucidated. Studies determining the relationship between the ovarian response pattern with the follicle status present before the introduction of rams (Ungerfeld et al. 2004b), the follicular development after the introduction of rams (Pearce et al. 1987), the uterine effect on early luteolysis (Lassoued et al. 1997) and the possible existence of spontaneous short luteal phases produced by luteinised follicles or short-lived corpora lutea during the anoestrous season (Ferreria et al. 2005) have all failed to provide a definitive answer. A recently published review provides a working hypothesis of the physiological mechanisms involved (Chemineau et al. 2006).

Apparently in Merino sheep, in response to the introduction of the male a normal oestrous cycle will be induced in approximately $50 \%$ of the females while the other $50 \%$ will have first cycles with short luteal phases (Martin et al. 1986). However, in several experiments with Corriedale ewes we observed very few ewes in oestrus during the first expected period (days 17-19: Ungerfeld et al. 2003; Ungerfeld \& Rubianes 2004). Some factors related to the percentage of ewes that initially respond with normal or short luteal phases are summarized in Table 2. Oldham et al. (1985: see Table 2) in sheep and Luna-Orozco et al. (2005) in goats, observed a higher incidence of short luteal phases in adult compared to young females. However, in sheep this has not been confirmed by other researchers (Thimonier et al. 2000). In agreement with Khaldi (1984) and Thimonier et al. (2000), we observed that Corriedale ewes in poor body condition as a consequence of postpartum status, showed delayed oestrous behaviour compared to control animals $(25.8 \pm 0.3$ versus $24.6 \pm 0.4$ days after the introduction of the rams, $\mathrm{P}=0.03 ; \mathrm{R}$ Ungerfeld, unpublished data), suggesting that first ovulations were delayed or that a higher percentage of ewes responded initially with short luteal phases. 
A)

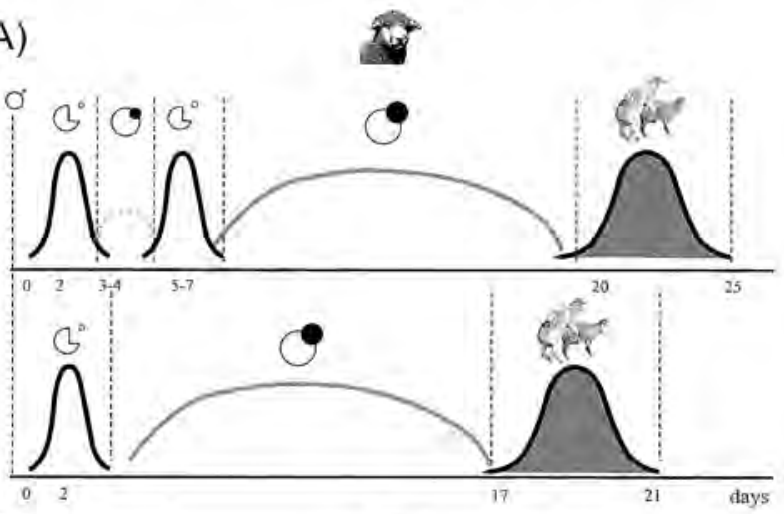

B)
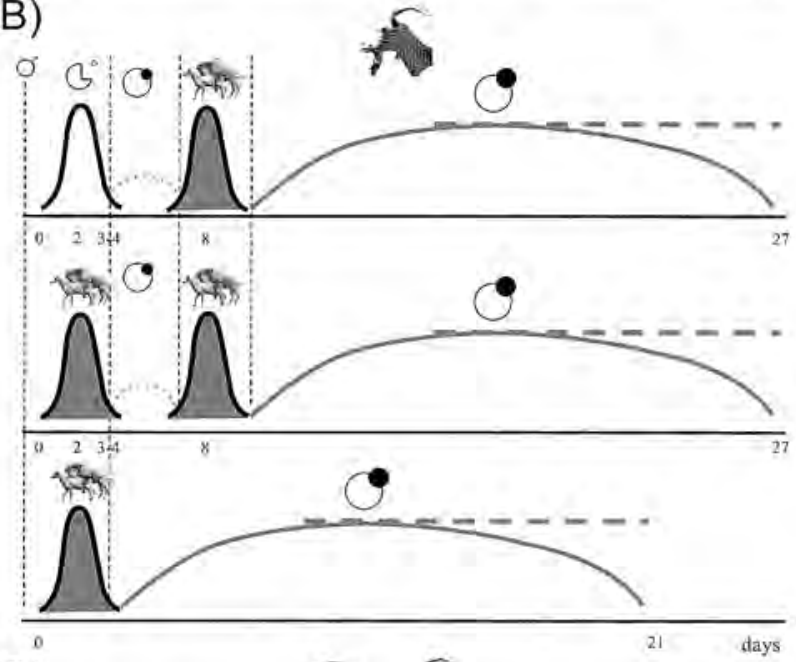

C)

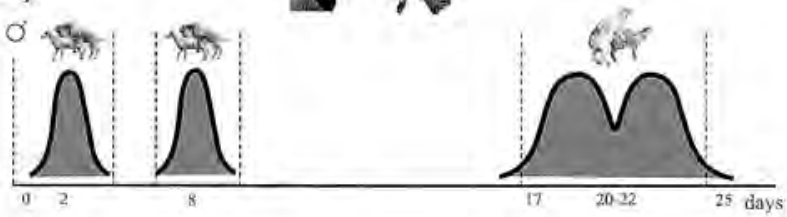

$0^{*}=$ introduction of males (rams or bucks)

$\bigwedge^{5}=$ ovulation

= short-life corpus luteum (- $=\mathrm{P}_{4}$ serum concentration)

- normal life corpus luteum ( - or $--P_{4}$ serum concentration)

= ewes in estrus

$\bigcap^{2}=$ goats in estrus

Fig. 1. Ovarian and behavioural response of A) ewes and B) does to the introduction of males. C) Synthetic scheme of the distribution of oestrus after the introduction of males in doe herds and ewe flocks. 
Table 2. Factors that influence the length of the first luteal phase after the introduction of rams. NLP = normal luteal phase; $S L P=$ short lutel phase.

\begin{tabular}{|c|c|c|}
\hline Factor & Effect & Reference \\
\hline \multicolumn{3}{|l|}{ Related to the stimuli } \\
\hline High ram's sexual behaviour & Decreases the incidence of SLP & Perkins \& Fitzgerald, 1994 \\
\hline \multicolumn{3}{|l|}{ Related to female status } \\
\hline Percenlage of cyclic ewes & Decreases the incidence of SLP & Lassoued, 1998 \\
\hline Underfeed ewes & Increases the incidence of SLP & Khaldi \& Lassoued, 1991 \\
\hline Increase of nutritional level & Decreases the incidence of SLP & Khaldi 1984; Thimonier et al. 2000 \\
\hline Postpartum interval & $\begin{array}{l}\text { Longer postpartum interval } \\
\text { decreases the incidence of SLP }\end{array}$ & Thimonier et al. 2000 \\
\hline Parity & $\begin{array}{l}\text { Maiden have a higher percentage } \\
\text { of NLP than adult }\end{array}$ & Oldham et al. 1985 \\
\hline Breed & $\begin{array}{l}\text { More Dorset than Hampshire ewes } \\
\text { seem to have SLP }\end{array}$ & Nugent III et al. 1988 \\
\hline
\end{tabular}

\section{Response to the male effect during the postpartum period in sheep and goats}

The physiology of postpartum anoestrus is influenced by different factors; such as suckling, season, nutritional status and age. Although this period has not been studied as much as seasonal anoestrus, the male effect has been used to induce breeding during the postpartum period in both sheep and goats.

The postpartum interval may be reduced if rams are introduced to ewes that have lambed in autumn or spring (Wright et al. 1989; Silva and Ungerfeld 2006). In autumn-lambing Merino ewes, it was observed that the percentage of ewes ovulating during the first 4 days after the introduction of the rams increases progressively from 21 to 45 days postpartum (Geytenbeek et al. 1984). In contrast to what happens in cattle, in autumn-lambing ewes, parity does not seem to influence the response to the ram effect. We have recently compared the response to the introduction of rams of multiparous and primiparous non-cyclic ewes during the breeding season (30 to 60 days postpartum) primed with medroxy-progesterone acetate for 12 days. Although the percentage of multiparous ewes that ovulated, which was determined by ultrasound scanning, tended to be higher than that of primiparous ewes $(92.5$ versus $79.3 \%, \mathrm{P}=0.08)$, the percentage that came into oestrus (88.8 versus $75.8 \%$ ) was not significantly different (SP González-Pensado, MA Ramos, T de Castro \& R Ungerfeld, unpublished results).

In one study performed during the non-breeding season, a similar percentage of postpartum ewes and ewes that had lambed several months before exhibited oestrus after the introduction of rams (Ungerfeld etal. 2004a). However, in agreement with Wright etal. (1990), probably as a consequence of suckling and low body condition, the conception rate was lower in the postpartum ewes. In ewes that had lambed during the non-breeding season Khaldi (1984) observed that the percentage of ewes that ovulated after the introduction of rams was higher at 75 days than at 15,30,45 or 60 days after parturition. It is interesting that in several experiments we observed a widespread distribution of oestrus, with ewes coming into oestrus on almost any day until 30 days after the introduction of rams. It remains to be elucidated as to how the range of physiological status between individuals present in a sheep flock affects the pattern of endocrine and ovarian responses to the introduction of rams.

\section{Determinants of the response of sheep and goats to the male effect}

In feral or wild populations, when males stimulate anoestrous females early before the onset of the breeding season, males have begun their reproductive recovery at least 40 to 60 days 
before. Therefore, females are stimulated by active males, which display their own maximum reproductive capacity. However, at the time of the year that may be of productive interest for farmers to induce ovulation and obtain pregnancies in their female flocks/herds, the males may not have recovered their maximum reproductive capacity from the preceding low capacity period. Thus, both the male and the female, and the stimuli derived from interactions between them, may determine the final response in a sheep flock or a goat herd.

\section{Male condition and stimulating capacity}

\section{Stimulating signals}

The stimulation of anoestrous females by males involves different cues; such as, odour, sound, visual or behavioural signals (reviewed by Walden-Brown et al. 1999; Delgadillo et al. 2006). The relative importance of each signal has varied in different experiments but this may be a consequence of using females in different states of responsiveness. In both sheep and goats, it has been reported that castrated males treated with androgens may be effective teasers suggesting that the involved cues are at least partially androgen-dependent (Fulkerson et al. 1981; Mellado \& Hernández 1996).

The scent of wool and wax from intact rams can be enough to trigger a response, in terms of ovulation, in ewes (Knight \& Lynch 1980). Similarly, odours from bucks' hair have been proven to stimulate $\mathrm{LH}$ secretion in does and ewes, and ovulation in anoestrous does (Over et al. 1990; Walkden-Brown et al. 1993). Interestingly, odours produced by the goat buck can also stimulate LH pulse frequency and ovulation in anoestrous ewes (Knight et al. 1983; Over et al. 1990). While Morgan et al. (1972) observed that ewes with impaired smell did not respond to rams, a normal LH response was observed in ewes reported without vomeronasal activity (CohenTannoudji et al. 1989). In agreement, Gelez et al. (2004a) demonstrated that inactivation of the neural projections of the main olfactory bulb (which includes projections from the olfactory epithelium) blocks the endocrine response to male odour, whereas inactivation of the projections from the accessory olfactory bulb (which come from the vomeronasal organ) has no effect. The destruction of the neuroreceptors of the olfactory epithelium blocked the endocrine response to the ram odour (Gelez \& Fabre-Nys 2004). A general overview of the neural pathways involved in the ewe's response to male odours has been recently provided by Gelez \& FabreNys (2006). They observed that although male odours activate pathways involving the accessory olfactory bulb, its role seems to be limited compared to that of the main olfactory bulb.

The maximum response of anoestrous ewes to the male was obtained after full ram contact compared with either contact through an open or an opaque fence, or the application of masks containing ram's wool (odour) (Pearce \& Oldham 1988). Similarly, a higher percentage of does ovulated after full contact with bucks than after odour stimulation alone (Walkden-Brown etal. 1993), Moreover, in sheep other authors observed that other sensory signals may completely replace the pheromone stimulus (Cohen-Tannoudji et al. 1986; 1989). Perkins \& Fitzgerald (1994) demonstrated the importance of the sexual behaviour of rams: a higher number of ewes ovulated after mixing them with high-than with low-serving capacity rams.

Overall, although the main stimulating cues are known, it seems that we are still far from determining the relative importance of each cue and how to manage them, as happens in swine, in which synthetic pheromones are utilized in production management.

\section{Male characteristics and management}

Little is known regarding those characteristics of the ram that may improve the percentage of 
anoestrous ewes that respond to teasing. Some authors observed that Dorset rams are better teasers than Suffolk, Romney, Romney X Finn or Coopworth rams (see Table 1 in review: Ungerfeld et al. 2004a).

At least under subtropical conditions, the reproductive activity of bucks is strongly depressed during the non-breeding season: plasma testosterone concentrations, sexual behaviour assessed by ano-genital sniffing, nudging and mounts, sexual odour and vocalizations are all at a low level (reviewed by Delgadillo et al. 2006). However, treatments with artificial long days and melatonin implants improve the biostimulatory effect of males. Therefore, these authors consider the reproductive condition of the buck as the limiting factor determining the response of anoestrous does to the male effect.

Another strategy to improve the stimulus of the male effect is to include a group of oestrous females when teasers are joined with anoestrous females (Rodríguez-Iglesias et al. 1991). Ewes in oestrus also influence the reproductive activity of rams, mainly by inducing an increase in LH pulse frequency and testosterone concentrations (Yarney \& Sanford 1983). The increases may continue for at least 4 days if ewes in oestrous are still present (Ungerfeld \& Silva 2004). While the increase in testosterone concentrations is similar in adult or yearling teaser rams, as happens during the developmental period (Sanford et al. 1982), LH concentrations reach higher values in yearling rams (Ungerfeld 2003). A possible explanation is that although concentrations are similar, testosterone may be less effective in yearling than in adult rams, as is reflected by a weak effect on the inhibition of pituitary activity. This may be attributed to an increase of feedback inhibition by androgens on the hypothalamo-pituitary axis during the developmental period (Foster et al. 1978) and/or to the maturation of the negative feedback mechanism (Courot et al. 1975). Therefore, as stimulating signals are related to androgen concentration, we compared the response of ewes to adult or yearling teasers. Significantly more ewes came into oestrus and ovulated after teasing with adult rather than with yearling teasers (MA Ramos \& R Ungerfeld, unpublished data: Fig. 2). Moreover, significantly more ewes ovulated after being stimulated with masks containing adult than yearling ram's wool $(53.3$ versus $29.8 \%$ : V Miller, M Cuadro \& R Ungerfeld, unpublished data). Therefore, the explanation of the greater effectiveness of adult than of yearling teasers is at least partially explained by quantitative and/or qualitative differences in odour secretion.

The effect of the presence of oestrous ewes is similar if teaser rams had been in contact with oestrous ewes for a short period before being joined with anoestrous ewes (Knight 1985). Rams that have been isolated from ewes and then placed with ewes in oestrus are more effective in stimulating ovulation in anoestrous ewes than are rams that have been in contact with ewes long before the procedure takes place (Knight et al. 1998).

\section{Depth of anoestrus}

Several parameters have been used to describe the "depth of anoestrus": such as, length of time until the ewe would spontaneously begin to cycle; arbitrary percentages of how many animals are cyclic; responsiveness to the introduction of rams; ovulation rate; $\mathrm{LH}$ pulse frequency; and basal circulating LH concentrations (Ungerfeld 2003). Thomas et al. (1988) proposed that differences between breeds in the depth of anoestrus could be related to differences in the sensitivity of the hypothalamus to both negative feedback by oestradiol and the direct effects of photoperiod. Overall, LH pulsatility has been consistently proposed as one parameter to assess the depth of anoestrus. We also observed that FSH concentrations before the introduction of rams were significantly higher in ewes that subsequently had a luteal phase than in those that do not (Ungerfeld et al. 2004a). 

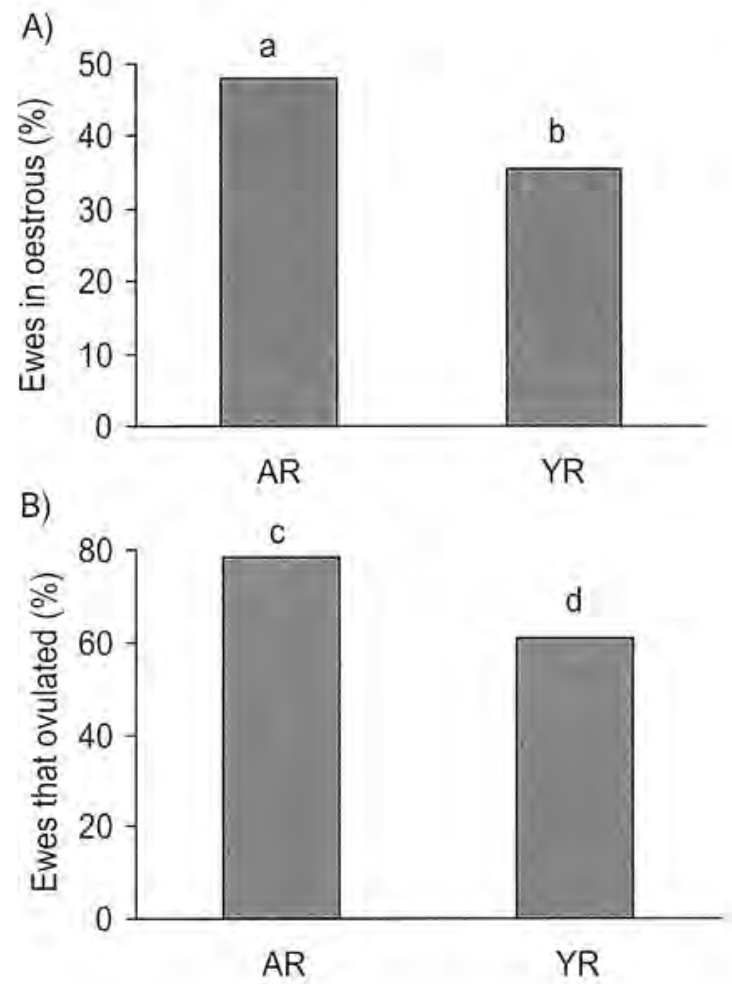

Fig. 2. Percentage of ewes that A) came into oestrus and B) ovulated after a 6-days medroxyprogesterone priming and the introduction of adult rams (AR) or yearling rams (YR) (MA Ramos \& R Ungerfeld, unpublished data). The experiment was performed during October (Southern Hemisphere, mid non-breeding season) with Merilin sheep.

The percentage of females that respond to the introduction of males is related to factors such as period of the anoestrous season, parity, previous experience of contact with males and breed (Oldham et al. 1985; Nugent III et al. 1988; Rodríguez-Iglesias et al. 1991; Restall 1992; Gelez et al. 2004b; Gelez \& Fabre-Nys, 2006). More ewes from a less seasonal breed (for example, Dorset) than from a more seasonal breed (for example, Hampshire) ovulate and conceive after stimulation with rams (Nugent III et al. 1988). Ewes from more seasonal breeds may not necessarily respond to the ram effect by ovulating even if they display an increase in $\mathrm{LH}$ pulsatility (Minton et al, 1991).

Management practices that may improve the effectiveness of stimulation in other breeds may be ineffective in strong seasonal breeds. Three hundred Lincoln ewes, strong seasonal breeders, were stimulated in two consecutive years during January (Southern Hemisphere) joining them with 10 rams from the same breed and twenty ewes in estrus. Forty-eight and 46 ewes were examined laparoscopically 5 days after joining in each year: 2/48 and 0/46 had ovulated (H Irazoqui \& RM Rodríguez-Iglesias, personal communication). In another recent experiment using another strong seasonal breed, 46 and 47 Texel ewes were joined during November (Southern Hemisphere) with 6 Texel rams that had been either isolated $(n=3)$ or kept near oestrous ewes for 3 days before $(n=3)$, respectively. Fifteen and nine ewes respectively were marked by the rams over the 25 days they were together although none of them 
became pregnant (MA Ramos, SP González-Pensado \& R Ungerfeld, unpublished data). As we could not discriminate the effects of photoperiod on males and females, it remains to be tested in these breeds whether strategies that are effective with bucks may overcome seasonal inhibition (reviewed by Delgadillo et al. 2006).

\section{Response to the male effect during the postpartum period in cattle}

In cattle, less is known about the physiological mechanisms by which cows respond to stimulation by the bull. Most trials have focused in trying to advance postpartum rebreeding, with very diverse outcomes. The diversity of outcomes and paucity of data makes it difficult to draw conclusions about the possibilities of using social stimuli in postpartum management.

As primiparous beef cattle have an especially long postpartum anoestrous period, it is interesting to determine the potential use of social-signals as stimulators of early rebreeding. The postpartum anoestrous interval in beef cows is shortened after bull introduction (Zalesky et al. 1984; Custer et al. 1990; Fernández etal. 1993; 1996; Rekwot etal. 2000; Landaeta-Hernández et al. 2004). Similar results have been also obtained with androgen-treated cows, suggesting (as in rams and bucks) that the bull stimulatory effect is also mediated by androgen stimulation (Burns \& Spitzer 1992). A female-female effect, has also been described which may result in ovulation (Wright et al. 1994). In both the bull and cow effect, it has been demonstrated that odours (probably pheromones) are the main stimulating cues (Izard \& Vandenbergh 1982; Anderson et al. 2002; Berardinelli \& Joshi 2005a). Moreover, it has been recently reported that social interactions between bulls and cows seem not to be necessary to obtain the maximum response (Berardinelli \& Joshi 2005a). Bull stimulation has been used to stimulate postpartum rebreeding in zebu and buffalo cattle as well as to advance puberty in beef cattle (Izard \& Vandenbergh 1982; Roberson et al. 1987; Bolaños et al. 1998; Roberson et al. 1991; Ingawale \& Dhoble 2004).

However, in some experiments cows failed to respond to bull stimulation (Naasz \& Miller 1987; Gifford et al. 1989). In the few experiments performed with dairy cattle, no positive response has been observed (Shipka \& Ellis 1998; 1999). However, in dual purpose cattle, bull teasing advanced rebreeding (Pérez-Hernández et al. 2002). There is also some contradictory information on the physiological mechanisms by which cows respond to bull stimulation: while Fernàndez et al. (1996) observed higher LH serum concentrations and pulsatility, this was not consistent with the results of Custer et al. (1990). If the increase of LH pulsatility is slower than that observed in small ruminants, the increase in $\mathrm{LH}$ may have not been detected due to the fact that individual animals may show an increase at different times after bull exposure.

The influence of many factors, such as body condition, nutritional status, season and postpartum interval, on the response to bull stimulation has been reported (Alberio et al. 1987; Monje et al. 1992; Stumpf et al. 1992; Larson et al. 1994; Berardinelli \& Joshi 2005b). Other factors, like bull familiarity to cows and the bulls' age (in contrast to what we observed with rams), seem not to affect the response (Cupp et al. 1993; Berardinelli et al. 2005). Considering the previous information, it is possible that when bulls are introduced, the diversity of physiological status present in a herd of postpartum cows, at least under extensive conditions, determines that many of them do not respond to the stimulation. If this happens with a significant percentage of cows, no response may be observed in the herd. Therefore, when cows gradually enter a responsive condition, the acute stimuli of bull introduction may have disappeared. Thus, the greater variation between individuals, compared with ewes or goats during seasonal anoestrus, may explain the lack of consistent and predictable results. 
Therefore, one strategy for synchronjzing parturition in cattle may be to obtain more homogeneous conditions within the herd. Another strategy may be to prolong the stimuli, allowing cows to respond individually as they develop better physiological conditions. We recently tested this strategy by comparing the time of postpartum rebreeding in two groups of multiparous cows which were extensively managed. At 30-60 days postpartum bulls were introduced to suckling Hereford and Angus cows. In one group, two bulls were changed every week to prolong the stimuli time, while the other group remained continuously with the same two bulls. After 7 weeks $91.1 \%$ and $47.8 \%$ of the cows from the groups with or without bull rotation, respectively, were cycling ( $P<0.001$ : V Miller, M Rodriguez-lrazoqui \& $R$ Ungerfeld, unpulished results).

\section{Overall view}

Overall, insights into the mechanisms involved in the natural socio-sexual stimulation of wild or feral ruminants will promote the inclusion of these management techniques in domestic ruminant production. Better comprehension of the involved mechanisms, strategies to strengthen the stimuli according to female condition and the use of different stimulating techniques may open interesting perspectives. The challenge for researchers is to develop standardized treatments with predictable results in strong seasonal breeds of sheep and goats and during the postpartum period in the three species. We are still far from developments such as those used in swine, in which the application of synthetic stimulating odours to induce ovulation in females is commonly used in reproductive management.

\section{Acknowledgements}

I gratefully acknowledge: Dr. Edgardo Rubianes and Dr. Mats Forsberg, for their participation in many of the experiments and continuous support; Dr. Andrea Pinczak, Bettina Carbajal, Leticia Silva and María Alejandra Ramos, my collaborators for some of the experiments; and both Milton Pintos and Alejandro Salina, for caring for the animals in many of the experiments. I am especially grateful to Jennifer Brown for her helpful work with language revision. Financial support for the experiments was provided by CSIC (Universidad de la República, Uruguay), CIDEC (Facultad de Veterinariá, Uruguay), Fondo Clemente Estable (Ministerio de Educación y Cultura, Uruguay) and the Department of Clinical Chemistry (Swedish University of Agricultural Sciences, Sweden).

\section{References}

Adams CA, Bowyer RT, Rowell JE, Hauer WE \& Jenks JA 2001 Scent marking by male caribou: an experimental test of rubbing behavior. Rangifer 21 21-27.

Alberio H, Schiersmann G, Carou N \& Mestre J 1987 Effect of a teaser bull on ovarian and behavioural activity of suckling beef cows. Animal Reproduction Science 14 263-272.

Amoah EA \& Bryant M 1984 A note on the effect of contact with male goats on occurrence of puberty in female goat kids. Animal Production 38 141-144.

Anderson KA, Berardinelli JG, Joshi PS \& Robinson B 2002 Effects of exposure to bull or bull excretory products of bulls on the breeding performance of first-calf restricted suckled beef cows using a modified CO-Synch protocol. In Realistic solutions for maintaining the sustainability of Montana's livestock industry. Proceedings of the Montana Nutrition Conference, May 7-8, GranTree Inn, Bozeman, Monlana, USA.

Berardinelli JG \& Joshi SA 2005a Iniliation of postparfum luteal function in primiparous restricted-suckled beef cows exposed to a bull or excretory products of bulls or cows, Journal of Animal Science 832495 2500. 
Berardinelli JG \& Joshi SA 2005b Introduction of bulls at different days postpartum on resumption of ovarian cycling activity in primiparous beef cows. Journal of Animal Science $832106-2110$.

Berardinelli JG, Joshi SA \& Tauck SA 2005 Postpartum resumption of ovarian cycling activity in first-calf suckled beef cows exposed to familiar or unfamiliar bulls. Animal Reproduction Science 90 201-209.

Bérubé CH, Festa-Bianchet M \& Jorgenson JT 1999 Individual differences, longevity, and reproductive senescence in Bighorn ewes. Ecology $\mathbf{8 0}$ 2555-2565.

Blanvillain C, Ancrenaz M, Delhomme A, Greth A \& Sempére A 1997 The presence of the male slimulates puberty in captive female Arabian oryx (Oryx leucoryx Pallas, 1777). Journal of Arid Enviromments 36359 366.

Bolaños IM, Forsberg M, Kindahl H \& RodríguezMartínez H 1998 Biostimulatory effects of estrous cows and bulls on resumption of ovarian activity in postpartum anestrous zebu (Bos indicus) cows in the humid tropics. Theriogenology 49 629-636.

Burns PD \& Spitzer JC 1992 Influence of biostimulation on reproduction in postpartum beef cows. journal of Animal Science 70 358-362.

Chemineau P 1985 Effects of a progestagen on buckinduced short ovarian cycles in the Creole meat goat. Animal Reproduction Science 9 87-94.

Chemineau P, Pellicer-Rubio M-T, Lassoued N, Khaldi G \& Monniaux D 2006 Male-induced short oestrous and ovarian cycles in sheep and goats: a working hypothesis. Reproduction Nutrition Development 46 $417-429$.

Claus R, Kaufmann B, Dehnhard M \& Spitzer V 1999 Demonstration of 16-unsaturated C- 19 steroids ("boar pheromones") in tissues of the male camel (Camelus. dromedarius). Repraduction in Domestic Animals 34 455-458.

Cohen-Tannoudji I, Lavenet C, Locatelli A, Tillet Y \& Signoret JP 1989 Non-involvement of the accessory olfactory system in the $\mathrm{LH}$ response of anoestrous ewes to male odour. Journal of Reproduction and Fertility 86 135-144.

Cohen-Tannoudji J, Locatelli A \& Signoret JP 1986 Nonpheromonal stimulation by the male of $\mathrm{LH}$ release in the anoestrous ewe. Physiology \& Behavior 36 921-924.

Courot M, De Reviers M-M \& Pelletier I 1975 Variations in pituitary and blood $\mathrm{LH}$ during puberty in the male lamb. Relation to time of birth. Annales de Biologie Aninale Biochimie Biophysique 15 509-516.

Cupp AS, Roberson MS, Stumpf TT, Wolfe MW, Werth LA, Kojima N, Kittok RJ \& Kinder JE 1993 Yearling bulls shorten the duration of postpartum anestrus in beef cows to the same extent as do mature bulls. Journal of Animal Science 71 306-309.

Custer EE, Berardinelli JB, Short RE, Wehrman M \& Adair R 1990 Pospartum interval to estrus and patterns of $\mathrm{LH}$ and progesterone in first-call suckled beef cows exposed to mature bulls. lournal of Animal science $68 \quad 1370-1377$.
Delgadillo JA, Fitz-Rodríguez G, Duarte G, Veliz FG, Carrillo E, Flores JA, Vielma J, Hernández $\mathrm{H}$ \& Malpaux B 2004 Management of photoperiod to control caprine reproduction in the subtropics. Reproduction Fertility and Development 16 471-478.

Delgadillo JA, Flores JA, Veliz FG, Duarte G, Vielma J, Hernández H \& Fernández IG. 2006. Importance of the signals provided by the buck for the success of the male effect in goats. Reproduction Nutrition Development 46 391-400.

Fernández DL, Berardinelli JG, Short RE \& Adair R 1993 The time required for the presence of bulls to alter the interval from parlurition to resumption of avarian activity and reproductive performance in firstcalf suckled beef cows. Theriogenology 39 411-419.

Fernández DL, Berardinelli JB, Short RE \& Adair R 1996 Acute and chronic changes in luleinizing hormone secretion and postpartum interval to estrus in firstcalf suckled beef cows exposed continuously or intermittently to mature bulls. Journal of Animal Science 74 1098-1103.

Ferrería J, Rodríguez-Iglesias RM, Ciccioli NH, Pevsner DA \& Rosas CA 2005 Características del cuerpo lúteo de ovejas Corriedale en anestro tratadas con acetato de medroxiprogestrona (MAP) en diferentes momentos previo a una bioestimulación. In 28 Congreso Argentino de Producción Animal. Bahia Blanca, Buenos Aires, Argentina: Revista Argentina de Producción Animal 25, Supplement 1117.

Fisher MW, Meikle LM \& Johnstone PD 1995 The influence of the stag on pubertal development in the red deer hind. Animal Science 60 503-508.

Foster DL, Mickelson IH, Ryan KD, Coon GA, Drongowski RA \& Holt JA 1978 Ontogeny of pulsatile luteinizing hormone and testosterone secretion in male lambs. Endocrinology 102 1137-1146.

Fulkerson WJ, Adams NR \& Gherardi PB 1981 Ability of castrated male sheep treated with oestrogen or lestosterone to induce and detect oestrus in ewes. Applied Animal Ethology 7 57-66.

Geist V 1965 On the rutting behavior of the mountain goat. Journal of Mammalogy 45 551-568.

Geist V 1971 Mountain sheep. A study in behaviour and evolution. University of Chicago Press, Chicago, IL. USA.

Gelez H \& Fabre-Nys C 2004 The "male effect" in sheep and goats: a review of the respective roles of the two olfaclory syslems. Hormones and Behavior $\mathbf{4 6}$ 257- 271 .

Gelez H \& Fabre-Nys C 2006 Role of the olfactory syslems and importance of learning in the ewes' response to rams or their odours. Reproduction Nutrition Development 46 1-10.

Gelez H, Archer E, Chesneau D, Magallon T \& Fabre-Nys C 2004a Inactivation of the olfactory amygdala prevents the endocrine response to male odour in anoestrus ewes. European Journal of Neuroscience 19 1581-1590.

Gelez H, Archer E, Chesneau D, Campan R \& Fabre-Nys C 2004b Importance of learning in the response of 
ewes to male odor. Chemical Senses 29 555-563.

Geylenbeek PE, Oldham CM \& Gray SJ 1984. The in duction of ovulation in the post partum ewe. Proceedings of the Australian Society of Animal Production $15353-356$.

Gifford DR, D'Occhio MJ, Sharpe PH, Weatherly T \& Pittar RV 1989 Return to cyclic ovarian activity following parturition in mature cows and first-calf heifers exposed to bulls. Animal Reproduction Science 19209212.

Green MJB 1987 Scent-marking in the Himalayan musk deer (Moschus chrysogaster). Joumal of Zoology, London (B) 1 721-737.

Grubb P \& Jewell PA 1973 The rut and the occurrence of oestrus in the Soay sheep on St Kilda. lournal of Reproduction and Fertility (Supplement) 19 491-502.

Hogg JT, Hass CC \& Jenni DA 1992 Sex-biased maternal expenditure in Rocky Mountain bighorn sheep. Behavioral Ecology and Sociobiology 31 242-251.

Hosack DA, Miller KV, Ware LH, Mashburn KL, Morrow CJ, Williamson LR, Marchinton RL \& Monfort SL 1999 Stag exposure advances the LH surge and behavioral estrus in Eld's deer hinds after CIDR device synchronization of estrus. Theriogenology $\mathbf{5 1}$ 1333-1342.

Ingawale MV \& Dhoble RL 2004 Buffalo reproduction in India: an overview. Buffalo Bulletin 23 4-9.

Izard MK \& Vandenbergh JG 1982 The effects of bull urine on puberty and calving date in crossbred beef heifers. Journal of Animal Science 55 1160-1168.

Jewell PA 1976 Selection for reproductive success. In The evolution of reproduction, pp 71-109. Eds CR Austin and RV Short. Cambridge: Cambridge University Press.

Jewell PA 1997 Survival and behaviour of castrated Soay sheep (Ovis aries) in a feral island population on Hirta, St. Kilda, Scotland. Journal of Zoology 243 623-636.

Khaldi G 1984 Variations saisonniêres de l'activité ovarienne, du comportement d'oestrus et de la durée de l'anoestrus post-partum des femelles ovines de race Barbarine: influence du niveau alimentaire et de la présence du mâle. PhD Thesis, UST Languedoc, France.

Khaldi G \& Lassoued N 1991 Interactions nutrition-reproduction chez les petits ruminants en milieu méditerranéen. In Proceedings of the International Symposium on Nuclear and Related Techniques in Animal Production and Health. AIEA/FAO, 15-19 April, Vienna pp 379-390.

Knight TW 1985 Are rams necessary for the stimulation of anoestrous ewes with oestrous ewes? Proceedings of the New Zealand Society of Animal Production $\mathbf{4 5}$ 49-50.

Knight TW \& Lynch PR 1980 Source of ram pheromones that stimulate ovulation in the ewe. Animal Reproduction Science 3 133-136.

Knight TW, Tervit HR \& Lynch PR 1983 Effects of boar pheromones, ram's wool and presence of bucks on ovarian activity in anovular ewes early in the breed- ing season. Animal Reproduction Science 6 129-134.

Knight TW, Ridland M \& Litherland AJ 1998 Effect of prior ram-ewe contact on the ability of rams to stimulate early oesirus. Proceedings of the New Zealand Society of Animal Production 58 178-180.

Komers PE, Birgersson B \& Ekvall K 1999 Timing of estrus in fallow deer is adjusted to the age of available mates. The American Naturalist 153 431-436.

Landaeta-Hernández $\mathrm{A}$, , Giangreco $\mathrm{M}$, Meléndez $\mathrm{P}_{r}$ Bartolomé J, Bennet F, Rae DO, Hernández J \& Archbald LF 2004 Effect of biostimulation on uterine involution, early ovarian activity and first postparfum estrous cycle in beef cow5. Theriogenology 61 $1521-1532$.

Larson CL, Miller HL \& Goehring TB 1994 Effect of postpartum bull exposure on calving intrval of first. calf heifers bred by natural service. Canadian Journal of Animal Science 74153-154.

Lassoued N 1998 Induction de l'ovulation par "effel bélier" chez les brebis de race Barbarine en anoestrus saisonnier. Mécanismes impliqués dans l'existence du cycle ovulatoire de courte durée. PhD Thesis, Univ Tunis II.

Lassoued N, Khaldi N, Chemineau P, Cognie Y \& Thimonier I 1997 Role of the ulerus in early regres. sion of corpora lutea induced by the ram effect in seasonally anoestrous Barbarine ewes. Reproduc. tion Natrition Development 37 559-571.

Lincoln GA \& Davidson W 1977 The relationship be tween sexual and aggressive behaviour, and pitu. itary and testicular activity during the seasonal sexual cycles of rams, and the influence of the photoperiod. Joumal of Reproduction and Fertifity 49 267-276.

Lincoln GA \& Short RV 1980 Seasonal breeding: nature's contraceptive. Recent Progress in Hormone Research $361-43$.

Luna-Orozco JR, Flores JA, Hernández H, Delgadillo JA \& Fernández IG 2005 La respuesta de la actividad estral de las cabras nuliparas no difiere de las multiparas al someterlas al efecto macho. In Proceed ings of the Memorias de la XX Reuniỏn Nacional sobre Caprinocultura, October 5-7, Universidad Autónoma de Sinaloa, Asociación Mexicana de Producción Caprina, Culiacán Sinaloa, México, pp 397-401.

Martin GB, Scaramuzzi RJ \& Lindsay DR 1983 Effect of the introduction of rams during the anoestrous season on the pulsatile secretion of $\mathrm{LH}$ in ovariectomized ewes. Journal of Reproduction and Fertilility $6747-55$.

Martin GB, Oldham CM, Cognie Y \& Pearce DT 1986 The physiological responses of anovulatory ewes to the introduction of rams - a review. Livestock Production Science $15219-247$.

Martin GB, Milton ITB, Davidson RH, Banchero Hunzicker GE, Lindsay DR \& Blache 2004 Natural methods for increasing reproductive efficiency in small ruminants. Animal Reproduction Science $\mathbf{8 2} / \mathbf{8 3}$ 231-246.

Mauget R 1981 Behavioural and reproductive strategies in wild forms of Sus scrofa (European wild and 
feral pigs). In The welfare of pigs. Ed W Sybesma. Current Topics in Veterinary Medicine and Animal Science 11 3-13.

McClelland BE 1991 Courtship and agonistic behavior in mouflon sheep. Applied Anmal Behaviour 5cience 29 67-85.

Mellado M \& Hernández IR 1996 Ability of androgenized goat wethers and does to induce estrus in goats under extensive conditions during anestrus and breeding seasons. Small Ruminant Research $2337-42$.

Mellado M, Olivas R \& Ruiz F 2000 Effect of buck stimulus on mature and pre-pubertal norgestomet-treated goats. Small Ruminant Research 36 269-274.

Minton JE, Coppinger TR, Spaeth CW \& Martin IC 1991 Poor reproductive response of anestrus Suffolk ewes to ram exposure is not due to failure to secrete luteinizing hormone aculely. Journal of Animal Science 69 3314-3320.

Miquelle DG 1991 Are moose mice? The function of scent urination in moose. American Naturalist 138 460-477.

Monje AR, Alberio R, Schiersmann G, Chedrese J, Carou N \& Callejas S 1992 Male effect on the post-partum sexual activity of cows maintained on two nutritional levels. Animal Reproduction Science 29 145-156.

Moore GH \& Cowie GM 1986 Advancement of breeding in non-laclating adult red deer hinds. Proceedings of the New Zealand Society of Animal Production 46 175-178.

Morgan PD, Arnold EW \& Lindsay DR 1972 A note on the mating behaviour of ewes with various senses impaired. Journal of Reproduction and Fertility $\mathbf{3 0}$ $151-152$.

Naasz CD \& Miller HL 1987 Effecls of bull exposure on postpartum interval and preproduclive performance in beef cows. Journal of Animal Science 65 (Supplement) 426.

Nugent III RA, Notter DR \& Beal WE 1988 Effects of ewe breed and ram exposure on estrous behavior in May and June. Journal of Animal Science 66 13631370.

O'Riordan EG \& Hanrahan JP 1989 Advancing first estrus in ewe lambs. Farm and food Research 2025 27.

Oldham CM, Pearce DT \& Gray SJ 1985 Progesterone priming and age of ewe affect the life-span of corpora luted induced in the seasonally anovulatory Merino ewe by the "ram effect". Jourmal of Reproduction and Fertility 75 29-33.

Over R, Cohen-Tannoudji J, Dehnhard M, Claus R \& Signoret JP 1990 Effect of pheromones from male goats on LH-secretion in anoestrous ewes. Physiology \& Behavior $\mathbf{4 8}$ 665-8.

Pearce GP \& Oldham CM 1988 Importance of non-olfaclory ram stimuli in mediating ram-induced ovulation in the ewe, lournal of Reproduction and Fertitity $\mathbf{8 4}$ 333-339.

Pearce DT, Oldham CM, Haresign W \& Gray S] 1987 Effects of duration and timing of progesterone prim. ing on the incidence of corpora lutea with a normal life-span in Merino ewes induced to ovulate by the introduction of rams. Animal Reproduction Science 13 81-89.

Pérez-Hernández $P$, García-Winder M \& GallegosSánchez J 2002 Bull exposure and an increased within-day mlking to suckling interval reduced postpartum anoestrus in dual purpose cows. Animal Reproduction Science 74 111-119.

Perkins A \& Fitzgerald JA 1994 The behavioral component of the ram effect: the influence of ram sexual behavior on the induction of estrus in anovulatory ewes, Joumal of Animal Science 72 51-55.

Reinhardt C, Reinhardt A \& Reinhardt V 1986 Social behaviour and reproductive performance in semiwild Scottish highland cattle. Applied Animal Behavior Science 15 125-136.

Rekwot PI, Ogwu D, Oyedipe EO \& Sekoni VO 2000 Effects of bull exposure and body growth on onset of puberty in Bunaji and Friesian X Bunaji hiefers. Reproduction Nutrition Development 40 359-367.

Restall BJ 1992 Seasonal variation in reproductive activity in Australian goats. Animal Reproduction $5 \mathrm{ci}-$ ence 27 305-318.

Roberson MS, Ansotegui RP, Berardinelli JG, Whitman RW \& Mcinerney MJ 1987 Influence of biostimulation by mature bulls on occurrence of puberty in beef heifers. Journal of Animal Science 64 1601-1605.

Roberson MS, Wolfe MW, Stumpf TT, Werth LA, Cupp AS, Kojima ND, Wolfe PL, Kittok RJ \& Kinder JE 1991 Influence of growth rate and exposure to bulls on age at puberty in beef heifers. Journal of Animal Science 69 2092-2098.

Rodriguez-Iglesias RM, Ciccioli N, Irazoqui H \& Rodriguez BT 1991 Importance of behavioural stimuli in ram-induced ovulation in seasonally anovular Corriedale ewes. Applied Animal Behavior Science 30 323-332.

Rowlands IW \& Weir BI 1984 Mammals: non-primate eutherians. In Marshall's Physiology of Reproduction. Vol. 1. Reproductive cycles of vertebrates, edn 4 , pp 455-658. Ed GE Lamming. Churchill Livingstone, Edinburgh, London, Melbourne, and New York.

Sanford LM, Palmer WM \& Howland BE 1982 Influence of age and breed on circulating LH, FSH and testosterone levels in the ram. Canadian Journal of Animal Science 62 767-776.

Schaller G \& Mirza ZB 1974 On the behaviour of Punjal Urial Ovis orientalis punjabensis. In The behaviour of ungulates and its relation to management. Vol. 1. Ed5 V Geist \& FR Walther. IUCN Publications, Morges, Swilzerland.

Shackleton DM \& Shank CC 1984 A review of the social behavior of feral and wild sheep and goats. Journal of Animal Science 58 500-509.

Shipka MP \& Ellis LC 1998 No effects of bull exposure on expression of éstrous behavior in high-producing dairy cows. Applied Animal Behaviour Science 57 17.

Shipka MP \& Ellis LC 1999 Effects of bulf exposure on 
postpartum ovarian activity of dairy cows. Animal Reproduction Science 54 237-244.

Shipka MP, Rowell JE \& Ford SP 2002 Reindeer bull introduction affects the onset of the breeding season. Animal Reproduction Science 72 27-35.

Silva L \& Ungerfeld R 2006 Reproductive response in suckling Corriedale ewes to the ram effect during the non-breeding season: effect of postpartum condition and of the use of medroxyprogesterone primings. Tropical Animal Health and Production $\mathbf{3 8} 365$ $-369$

Skinner DC, Cilliers SD \& Skinner JD 2002 Effect of ram introduction on the oestrous cycle of springbok ewes (Antidorcas marsupialis). Reproduction 124 509-513.

Skinner JD, Jackson TP \& Marais AL 1992 The "ram effect" in three species of African Ungulates. Ungulates $91565-568$.

Stricklin WR \& Mench JA 1987 Social Organization. In Farm Animal Behavior. Ed EO Price, WB Saunders Company. The Veterinary Clinics of North America, Food Animal Practice 3 307-322.

Stumpf TT, Wolfe MW, Wolfe PL, Day ML, Kittok RJ \& Kinder JE 1992 Weight changes prepartum and presence of bulls pospartum interact to affect duration of postpartum anestrus in cows. Journal of Animal Science 70 3133-3137.

Thimonier J, Cognie Y, Lassoued N \& Khaldi G 2000 L'effet mâle chez les ovins: une technique actuelle de maîtrise de la reproduction. INRA Productions Animales 13 223-231.

Thomas GB, Pearce DT, Oldham CM, Martin GB \& Lindsay DR 1988 Effects of breed, ovarian steroids and season on the pulsatile secretion of LH in ovariectomized ewes. Journal of Reproduction and Fertility 84 313-324.

Underwood EJ, Shier FL \& Davenport N 1944 Studies in sheep husbandry in W.A.V. The breeding season of Merino, crossbreed and British Breeds ewes in the agricultural districts. Journal of Agriculture W. A. 11, Series 2 135-143.

Ungerfeld R 2003. The reproductive response of anestrous ewes to the introduction of rams. Ph.D. Thesis, Swedish University of Agricultural Sciences, Uppsala, Sweden. Acta Universitatis Agriculturae Sueciae, Veterinaria 163, pp. 66.

Ungerfeld R 2005 Sixly years of the ram effect (19442004): how we have learned what we know about it? Journal of Animal and Veterinary Advances 4 698701.

Ungerfeld R \& Rubianes E 2004 Estrous distribution in anestrous ewes primed with estradiol-17beta 3 or 5 days before the introduction of the rams (the ram effect). In Proceedings of the International Congress of Animal Reproduction, August 8-12, Porto Seguro, Brasil.

Ungerfeld R \& Silva L 2004 Ewe effect: endocrine and testicular changes in adult and young Corriedale rams used for the ram effect. Animal Reproduction Science $\mathbf{8 0}$ 251-259.
Ungerfeld R, Pinczak A, Forsberg M \& Rubianes E 2002 Ovarian and endocrine responses of Corriedale ewes to "ram effect" in the non-breeding season. Canadian Joumal of Animal Science 82 599-602.

Ungerfeld R, Suárez G, Carbajal B, Silva L, Laca M, Forsberg M \& Rubianes E 2003 Medroxyprogesterone priming and response to the ram effect in Corriedale ewes during the nonbreeding season. Theriogenology $6035-45$.

Ungerfeld R, Forsberg M \& Rubianes E 2004a Overview of the response of anoestrous ewes to the ram effect. Reproduction Fertility and Development $16479-490$.

Ungerfeld R, Dago Al, Rubianes E \& Forsberg M 2004b Response of anestrous ewes to the ram effect after follicular wave synchronization with a single dose of estradiol-17beta. Reproduction Nutrition Development 44 1-10.

Walkden-Brown SW, Restall BJ \& Henniawati. 1993 The male effect in Australian cashmere goats 2. Role of olfactory cues from the male. Animal Reproduction Science 32 55-67.

Walkden-Brown SW, Martin GB \& Restall BJ. 1999. Role of male-female interaction in regulating reproduction in sheep and goats. Journal of Reproduction and Fertility (Suppl.) 52 243-257.

Whittle CL, Bowyer RT, Clausen IP \& Duffy LK 2000 Putative pheromones in urine of rutting male moose (Alces alces): evolution of honest advertisement? journal of Chemical Ecology 26 2747-2762.

Wright PJ, Geytenbeek PE, Clarke IJ \& Hoskinson RM 1989 The efficacy of ram introduction, GnRH administration, and immunisation against androstenedione and oestrone for the induction of oestrus and ovulation in anoestrous post-partum ewes. Animal Reproduction Science 21 237-247.

Wright PJ, Geytenbeek PE \& Clarke IJ 1990 The influence of nutrient status of post-partum ewes on ovarian cyclicity and on the oestrous and ovulatory responses to ram introduction. Animal Reproduction Science 23 293-303.

Wright IA, Rhind SM, Smith AJ \& Whyte TK 1994 Female-female influences on the duration of the postpartum anoestrous period in beef cows. Animal Production 59 49-53.

Yarney TA \& Sanford LM 1983 The reproduclive endocrine response of adult rams to sexual encounters with estrual ewes is season dependent. Hormones and Behavior 17 169-182.

Zalesky DD, Day ML, García-Winder M, Imakawa K, Kittok RJ, D'Occhio MJ \& Kinder IE 1984 Influence of exposure to bulls on resumption of estrous cycles following parturition in beef cows. Journal of Anima! Science 59 1135-1139. 